\title{
Perubahan Sosial Di Kawasan Benda Cagar Budaya Sangiran: Studi Tentang Perubahan Perilaku
}

\section{Bambang Soelistyanto}

Keywords: cultural resource management, conservation, heritage, ethnoarchaeology

\section{How to Cite:}

Soelistyanto, B. (1996). Perubahan Sosial Di Kawasan Benda Cagar Budaya Sangiran: Studi Tentang Perubahan Perilaku. Berkala Arkeologi, 16(2), 28-41. https://doi.org/10.30883/jba.v16i2.751

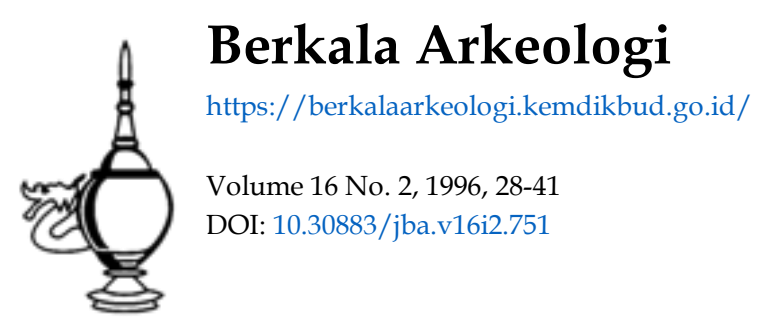

\section{c) (7) (2)}

This work is licensed under a Creative Commons Attribution-NonCommercial-ShareAlike 4.0 International License. 


\title{
PERUBAHAN SOSIAL \\ DI KAWASAN BENDA CAGAR BUDAYA SANGIRAN: \\ Studi Tontang Perubahan Perllaku
}

\author{
Bambang Sulistyanto \\ (Balai Arkeologi Yogyakarta)
}

\section{Penalaran}

Masyarakat dan kebudayaan manusia di manapun berada selalu akan mengalami perubahan. Proses cepat atau lambatnya perubahan antara masyarakat satu dengan masyarakat yang lain berbeda-beda Fada masyarakat yang hidup terisolasi jauh dari jalur hubungan dengan masyarakat lain, akan mengalamı perubahan yang lambat dibanding masyarakat yang berada di perkotaan Sorokin (1841:92) berpandangan banwa perubahan merupakan hal yang normal, karena manusia senantiasa berusaha dan berjuang untuk memenuhi keperluan hidupnya.

Adanya perubahan sosial disebabkan oleh beberapa hal yang melatatinya. Pertama, pertambshan penduduk dapat menimbulkan porubahari ekologis yang diikuti dengan terjadinya perubahan tata hubungan antar kelompok sosial. Kedua, Penemuan-penemuan dan inovasi teknologis dapat menımbuikan suatu tatanan baru dalam kehidupan perekonomian. Dan ketiga, perubahan ideologi dasar suatu masyarakat akan menimbulkan kekuatan-kekuatan terjadinya perubahan perilaku

Stuart Chapin (1958) menyatakan terjadinya perubahan sosiai tampak dalam tiga gejala, yaitu gejala biologis, kultural, dan ideologis Untuk memahami perbedaan ini, menurutnya penting untuk dipahamı konsep kebudayaan secara umum termasuk semua kekuatan yang ada pada manusia untuk menguasai alam dan dirinya sendiri.

Pengertian dan konsep perubahan sosial dengan perubahan budaya memiliki perbedaan dan persamaan. Perbedaan antara perubahan sosial dengan perubahan kebudayaan terletak pada tingkat analisisnya saja (Selo Sumarjan, 1991:3-5), namun demikian, dalam bahasan perubahan sosial tidak dapat diketahui pengertiannya secara benar jika tidak dikaitkan dengan bahasan perubahan kebudayaan (Parsudi, 1986 105) Adapun persamaan konsep perubahan sosia! dengan perubahan kebudayaan terletak pada adaptasi atau perbaikan masyarakat dalam menyiasatı dan memenuhı kebutuhan hidupnya Sehubungan dengan konsep tersebut pengertian kajlan perubahan dalam tulisan inı akan

Berkala Arkeologi Th. XVI - (2) 
mencakup pembahasan mengenai perubahan sosial dan perubahan kebudayaan

Berdasarkan pengertian dan konsep di atas, tulisan ini akan mencoba membahas adanya perubahan sosial yang terjadi di Desa Krikilan, Kecamatan Kalijambe, Kabupaten Sragen, Provins! Jawa Tengah. Desa ini terletak di kawasan Benda Cagar Budaya (BCB) Sangiran yang dilindungi oleh undang-undang Hal tersebut diangkat dalam tulisan ini, disebabkan adanya proses perubahan sosial yang unik dan hanya berlaku di desa ini Sejak desa IDT ini didatangi oleh para peneliti asing khususnya von Koenigsvald pada tahun 1934 dalam rangkz eksplorasi Situs Sangiran, disusul dengan berdirinya Museum Sangiran pada tahun 1974, dan kemudian diikuti oleh merebaknya sentra industri batuan (fosil) pada tahun 1980, perubahan sosial sangat banyak ditemukan di dalam kehidupan masyarakat Desa Kikilan.

Desa Krikilan dipilih sebagai obyek kajian dalam tulisan ini, didasarkan pada dua alasan mendasar. Pertama, masyarakat desa masih melanjutkan kebiasaan berburu fosil hingga sekarang. Kedua, desa terpilih memiliki latar belakang historis dalam konteks kehadiran para peneliti asing di kawasan BCB Sangiran. Dengan demikian, dari aspek "perburuan" fosil Situs Sangiran, desa ini menjadi pelopor di antara desa-desa lain di kawasan Situs Sangiran.

Bahasan mengenai masalah perubahan sosial daiam suatu masyarakat akan lebih esensial jika ditekankan pada kajian mengapa terjadi perubahan daripada masalah ada atau tidaknya perubahan. Dałami konteks inilah tulisan ini akan mengkaji masalah mengapa terjad: perubahan sosial pada masyarakat Desa Krikilan? Sedangkan perubahan sosial dalam bahasan kali ini terbatas pada persepsi masyarakat terhadap BCB di kawasan Situs Sangiran yang pada akhirnya mempengaruhi perubahan perilaku. Di samping itu, tulisan ini akan mengkaji pula berbagai faktor pendorong terwujudnya perubahan sosial dalam kehidupan masyarakat.

Berdasarkan ketiga geiala perubahan sosial yang diungkapkan oleh Chapin, maka permasalahan yang mendasari tulisan ini adalah perubahan sosial yang berasal dari perubahan ideologi dasar yang terjadi pada masyarakat Desa Krikilan. Kajian tulisan ini Lebih mengkhususkan kajian perubahan perilaku yang diakibatkan oleh perubahan konsep nilainilai masyarakat Desa Krikilan terhadap benda warisan budaya (fosil) yang berada di lingkungan sekitarnya 


\section{Kondisi Dan Potensi Desa Krikilan}

\subsection{Habitat}

Desa Krikilan berada sekitar $4,5 \mathrm{~km}$ dari jalan raya Solo - Purwodadi atau $15 \mathrm{~km}$ dari Kabupaten Surakarta. Desa Krikilan merupakan salah satu desa yang masuk dalam kawasan Benda Cagar Budaya Sangiran yang sejak tahun 1977 dilindungi oleh undang-undang (SK Mendikbud, 1977). Luas wilayah desa sekitar 449,254 hektar, meliputi 64, 416 hektar tanah sawah dan 384,838 hektar tanah kering. Tanah kering terdiri dan 93,258 hektar tanah pekarangan, 281,362 hektar tegalan, sisanya 10,23 hektar berupa tanah kisik, yaitu berupa jalan, kuburan, dan lapangan.

Desa Krikilan berada pada ketinggian 125 meter di atas permukaan air laut membujur dari utara ke selatan dengan batas-batas sebelah utara berupa tegalan Desa Ngebung, sebelah selatan Sungai Cemoro, sebelah barat tegalan Desa Jetis, dan sebelah timur tegalan Desa Bukuran. Desa Krikilan merupakan salah satu desa yang padat akan kandungan benda warisan budaya khususnya berupa fosil manusia purba. Seperti halnya di desa-desa kawasan situs purbakala Sangiran Iainnya, kondisi tanah pertanian Desa Krikitan tidak begitu subur. Secara geografis letak desa ini lebih tinggi daripada Sungai Cemoro yang terletak di sebelah selatannya, sehingga air sungai ini tidak dapat dimanfaatkan sebagai pengairan sawah. Para petani dalam mengerjakan sawah sangat tergantung dari air hujan, sehingga mereka tidak bisa leluasa dalam memilih jenis tanaman yang akan ditanam.

Meskipun lahan tamah Desa Krikilan kurang mendukung untuk pertanian, namun pada kenyataannya sektor pertanian masih menjadi lapangan kerja yang paling dominan, sebagaimana ditunjukkan tabel 1 di bawah Sempitnya orientasi lapangan pekerjaan dan didukung tanah yang kurang subur untuk pertanian. merupakan salah satu faktor penyebab rendahinya taraf hidup masyarakat. 
Tabel 1. Mata Pencarian Penduduk Desa Krikilan Tahun 1995 Berdasarkan Umur 10 Tahun Ke atas.

\begin{tabular}{|l|r|r|}
\hline \multicolumn{1}{|c|}{$\begin{array}{c}\text { Jenis } \\
\text { Pekerjaan }\end{array}$} & Jumiah & Prosentase \\
\hline Petani & 859 & 33,5 \\
Brh tani & 941 & 36,6 \\
Pengusaha & 77 & 3,0 \\
Brh industri & 218 & 8,5 \\
Brh Bangunan & 342 & 13,3 \\
Pedagang & 106 & 4,1 \\
Angkutan & 2 & 0,1 \\
Peg Negen & 22 & 0,9 \\
\hline JUMLAH & 2567 & 100,00 \\
\hline
\end{tabular}

Sumber: Kecamatan Kalijambe dalam Angka, Tahun 1995.

Buruh tani dalam hal ini bukan pemilik tanah, menempati urutan pertama dalam matapencarian hidup berjumlah 941 orang atau $36,5 \%$ Sedangkan petani 859 orang atau $33,5 \%$ dan buruh bangunan 342 orang atau $13,3 \%$. Pengelompokkan ini didasarkan pada mata pencarian yang ditekuni tidak lebih dari separo waktu kerja. Hal tersebut disebabkam matapencarian ganda terjadi pula di Desa Krikilan. Seperti terjadi di desa. desa lain di Jawa, orang mencari penghasilan dari berbagai sumber pada waktu yang bersamaan atau berganti-ganti pekerjaan seirama dengan munculnya kesempatan kerja yang bersifat musiman

\subsection{Kondisi sosial ekonomi dan budaya.}

Tabel 1 di atas jugá menunjukkan, potensi di bidang perindustrian cukup berperanan dalam penyerapan tenaga kerja, tercatat 218 orang atau $8,5 \%$ dari jurntah keseluruhan usia kerja yang ada. Potensi industri di Desa Krikilan adalah jenis industri kecil dan rumah tangga Salah satu di antaranya adalah industri kerajinan batu atau fosil.

Fasilitas pengangkutan pribadi yang dimiliki oleh penduduk desa ini adalah sepeda berjumlah 194 buah, sepeda motor 21 buah, dan truk 1 buah (Mantri Statistik,199366). Akses berupa jalan aspal satu-satunya yang melewati Desa Krikilan menuju jalan utama Solo - Purwodadi dibuat sehubungan fungsi pariwisata budaya (Museum Sangiran) yang 
dikembangkan oleh pemerintah daerah Jalan beraspal menuju museum dan tersedianya sarana trasnportasi tersebut membuka kesempatan luas bagi warga desa untuk berinteraksı secara intensif dengan masyarakat kota

Pengamatan lapangan, memperlihatkan gerak mobilitas harian penduduk desa ini ke daerah perkotaan cukup tinggi. Setiap hari terdapat puluhan penduduk yang bepergian ke kota Surakarta karena di dorong oleh berbagai tujuan, antara lain, bekerja, sekolah atau berbelanja. Hal ini menunjukkan bahwa interaksi penduduk desa dengan masyarakat kota cukup tingoi.

Demikıan pula sebaliknya, keberadaan Museum Sangiran serta keha. diran industri kerajinan batu, menjadikan warga desa ini semakin luas interaksi mereka dengan masyarakat luar. Pungamatan memperlihatkan, seringnya beterapa turis asing maupun turis domestik yang secara individual mengunjungi beberapa sentra industri kerajinan batu di sana dengan berbagas ragam tujuan. Sedikit banyak realitas ini akan berpengaruh pada perilaku warga Desa Krikilan terhadap Benda Cagar Budaya Sangiran. Sebab, khususnya turis asing, menurut beberapa informan, tidak sedikit memesan fosil tertentu untuk tujuan yang beragam.

Potensi tersebut di atas menunjukkan, bahwa meskipun letak desa ini relatif jauh dengan perkotaan ( $17 \mathrm{~km}$, dari Surakarta), namun desa ini cukup terbuka terhadap sentuhan pengaruh masyarakat luar. Namun demikian jika dilihat dari kondisi masyarakatnya, desa ini masih merniliki ciri kuat sebagai desa bertipe pedesaan. Hal ini terlihat jelas dari mata pencarian penduduk dan jumlah fasilitas umum sebagaimana terdapat di perkotaan dibanding dengan yang tersedia di desa tersebut

\section{Perllaku Masyarakat Terhadap Benda Cagar Budaya.}

3.1. Perilaku Sebelum Kedatangan Peneliti Asing (1934).

Sikap dan perilaku sosial masyarakat terbentuk karena adanya interaksi sosial yang dialami oleh individu. Lebih jauh, interaksi sosial itu meliputi hubungan antara individu dengan lingkungan fisik maupun lingkungan psikologis di sekelilingnya (Azwar, 1988 24). Masyarakat Desa Krikilan sebelum kedatangan peneliti asing, memiliki sistem nilai budaya sebagai pedoman dan pendorong mereka berperilaku dalam kehidupan sehari-hari

Berabad-abad lamanya masyarakat Desa Krikilan percaya kepada mitos lokal yang mengkisahkan suatu peperangan besar yang terjadi di kawasan perbukitan Sangiran Dalam pertempuran itu, banyak raksasa yang gugur dan terkubur bukit. Oleh karena itu fosil-fosil yarng memang berukuran besar yang banyak bermunculan di kawasan perbukitan 
Sangiran tersebut dinamakan balung buto (tulang raksasa). Menurut Toto Marsono sesepuh Desa Krikilan yang berusia 89 tahun, tulang-tulang itu dahulu dipercaya dapat menyembuhkan berbagai penyakit, khususnya penyakit perut Bahkan air yang direndam bersama fosil-fosil itu jika diminum dipercaya dapat menambah kekuatan Selain itu, fosil tersebut menurut Toto Marsono, sering pula dicari oleh orang-orang Cina untuk ramuan obat "sinshe"

Oleh karena itu Fosil-fosil hewan atau manusia purba yang banyak bermunculan di berbagai tempat di permukaan tanah di kawasan situs. Sangiran khususnya setelah terkena erosi air hujan, jarang terganggu oleh masyarakat setempat. Bahkan fosil-fosil yang tidak lain adalah data penting guna rekonstruksi sejarah evolusi manusia, dibiarkan begitu saja yang pada gilirannya akan terpendam kembali oleh erosi bukit yang berada di atasnya. Karena persepsi religius-magis itulah, fosil-fosil sebagai ekofak yang tak ternilai bagi ilmu pengetahuan itu terselamatkan oleh kondisi alam Sangiran sendiri, kecuali ada warga masyarakat yang sakit, fosit itu baru dicari namun hanya terbatas pada kepentingan untuk ramuan obat.

Menurut Toto Marsono, karena jumlah fosil yang bermunculan itu melimpah khususnya pada musim penghujan, tidak sedikit petani yang justru terganggu karena cangkulnya sering membentur fosil. Dalam keadaan demikian, penduduk sering menumpuk fosil-fosil tersebut di tepian ladang, sekaligus dimanfaatkan untuk memperkeras dinding ladangnya. Dari informasi tersebut diperoleh pemahaman, bahwa meskipun fosil dipercaya memiliki nilai magis yang dapat menyembuhkan penyakit, namun pada aspek lain fosil tidak pernah dipersepsikan sebaga: sesuatu yang sakral

\subsection{Perilaku Antara Tahun 1934 - 1940.}

Hadirnya peneliti asing khususnya von Koenigswald pada tahun 1934 tidak disangka membawa perubahan besar pada sikap dan perilaku masyarakat Krikilan terhadap benda warisan budaya. Selama sekitar enam tahun 1934 - 1940 peneliti asing ini mengadakan eksplorasi di kawasan. Situs Sangiran dan untuk beberapa waktu lamanya dia tinggal di rumah Toto Marsono kepala Desa Krikilan waktu itu. Dalam rangka eksplorasi Situs Sangiran seluas sekitar $32 \mathrm{Km}$ persegi itu, Koenigswald melibatkan banyak penduduk Desa Krikilan untuk mencari fosil.

Dalam usahanya pengumpulan koleksi fosil, von Koenigswald menerapkan sistem upah atau pemberian hadiah berupa uang bagi penduduk yang berhasil menemukan, baik itu fosil manusia, hewan atau artefaktual lainnya. Besarnya hadiah itu menurut Toto Marsono (mantan 
Kades Krikilan yang sekaligus sobagai pemandu von Koenigsvald waktu itu), tergantung dari jumlah dan jenis fosil serta kelangkaannya.

Hadirnya von Koenigswald ahli paleantropologi di tengah-tengah masyarakat Desa Krikilan mombawa perubahan besar baik dari segi ilmu pengetahuan maupun perilaku yang tidak dikenal pada masa sebelumnya, yaitu berburu fosil untuk mendapatkan upah. Menurut Toto Marsono, pada masa itu pemuda-pemuda Krikilan benar-benar dilatih berburu fosil. Khususnya setelah hujan turun, mereka bersama-sama menuruni lembah menaiki bukit untuk mencari fosil. Setiap hari hasil perolehan fosil itu di letakkan di halaman Kantor Kepaia Desa Krikilan untuk diseleksi. Dalam batas-batas tertentu, di sini von Koenigswald mengajarkan identifikasi dan makna penting fosil bagi perkembangan ilmu pengetahuan, sekaligus. memberikan upah sebagai penggantinya.

\subsection{Perllaku Pasca Tahun 1940 - Sekarang.}

Perilaku masyarakat sekarang, pada hakekatnya adalah hasil belajar dari masyarakat sobelumnya, sehingga penyimpangan-penyimpangan adalah hasil belajar (yang kurang relevan) pada masa sebelumnya (Nimpoeno, 1980:26-30). Demikian pula yang terjadi pada masyarakat Desa Krikilan, sepeninggal von Koenigswald dari Situs Sangiran tahun 1940, perilaku berburu fosil ini terus dilanjutkan di bawah komando Toto Marsono. Semua hasil temuan penduduk itu dikumpulkan di rumahnya dan sebagian lagi ada yang telah dijual kepada orang yang memerlukan. Mempertimbangkan banyaknya temuan fosil di kawasan Situs Sangiran yang tidak terselamatkan, maka pada tahun 1974 atas Instruksi Gubernur KDH TK I Jawa Tengah, Pemerintah Daerah Tk. II Sragen mendinkan semacam Balai penyelamat fosil di Desa Krikilan yang akhirnya pada tahun 1988 berubah menjadi Museum Sangiran (Slamet, 1994:6).

Dengan berdirinya Museum ini. Desa Krikilan semakin banyak dikunjungi oleh wisatawan asing maupun domestik. Interaksi masyarakat Desa Krikilan dengan masyarakat luar (pengunjung museum) semakin terbuka. Sebagai akibatnya di Desa Krikilan bermunculan industri rumah berupa kerajinan batu-batuan. Industri kerajinan batu-batuan tersebut, dirintis sejak tahun 1980, đi bawah pengawasan Dinas Perindustrian Kabupaten Sragen yang sekarang telah berkembang hingga mencapai 35 home industri dengan produksi sekitar 100.000 buah kerajinan pertahun (Laporan tahunan Departemen Perindustrian Kabupaten Sragen, 1993/1994).

\footnotetext{
Hadiah itu berkisar antara 2 ketip sampai 5 sen. Tetapi jika penduduk bisa menemukan "untu bledek" (kapak Datu) von Koenigsvald berani mengganti uang sebesar Rp 5.- yang menurut perhitungan uang sebesar itu senilai dengan harga seekor lembu pada waktu itu (Wawancara dengan Toto Marsono)
}

Berkala Arkeologi Th. XV - (2) . 
Sebagai akibat muncuinya industri kerajinan tersebut, perilaku masyarakat terhadap fosil semakin kompleks. Mereka tidak hanya mencari fosil dan menjual tetapi juga mengubah fosil itu menjadi barang-barang kerajinan untuk dijual ke wisatawan. Pengamatan lapangan memperlihatkan, beberapa warga Desa Krikilan mahir dalam bidang pemalsuan bentuk asli fosil. Demikian pula sebaliknya, fragmen-fragmen fosil yang asli seringkali dibentuk dan dirubah sedemikian rupa menjadi barang-barang kerajinan untuk tujuan komersial. Aktivitas pemalsuan fosil tersebut, pada umumnya justru dilakukan di berbagai sentra industri kerajinan.

Bahkan menurut beberapa informan, ada indikasi tengkorak-tengkorak manusia dari makam-makam kuno di perbukitan dijarah kemudian dimodifikasi sedemikian rupa menjadi kesan fosil sungguhan (Sulistyanto, 1994). Perburuan dan sindikasi benda warisan budaya di situs Sangiran sudah mencapal taraf yang cukup memprihatinkan. Perilaku yang berdampak negatif bagi kelestarian benda warisan budaya ini, selain dilakukan oleh sekelompok orang yang cukup profesional, juga dikerjakan oleh beberapa petani setempat yang telah dihasut terlebih dulu oleh mereka yang memanfaatkan. Secara sederhana, kita dapat melihat pola hubungan sindikat fosil pada gambar di bawah ini:

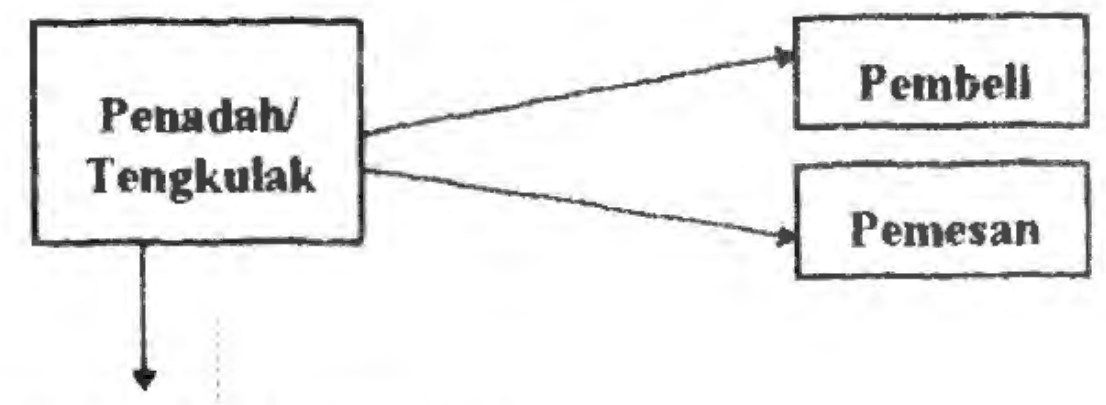

\section{Penduduk dan Pemburu}

Penadah atau tengkulak adalah pelaku I (pertama) yang memegang kunci dari keseluruhan proses transaksi benda warisan budaya, termasuk di dalamnya adalah penentuan harga dan pencarian pembeli. Sedangkan penduduk dan "pemburu" adalah pelaku II yang bekerja atas inisiatif pelaku | Perbedaan penduduk dan 'pemburu" terletak pada intensitas keterlibatannya. Keterlibatan penduduk dalam proses pencarian fosil hanya bersifat kebetulan pada saat mereka mengerjakan sawah atau aktivitas lainnya Sedangkan pemburu, secara sengaja memang mencari fosil untuk tujuan komersialisasi. Hasutan dari pelaku I inilah yang menyebabkan pelaku II (yang sebagian terbesar petani betaraf hidup rendah) akhisnya cenderung lebih memilih menyerahkan ke pada pelaku II daripada menverahkan temuannya kepada pemerintah sebagarmana terlihat pada kasus Subur Donald Tyler 
Di sint yang harus diperhatikan, adalah meskipun pelaku II bertindak atas inisıatif pelaku I, dalam prakteknya justru pelaku II begitu menemukan fosil merasa memerlukan jasa dari pelaku I untuk mengkomersiilkan fosil temuannya Di sini barulah pelaku II tersebut mencarikan pembeli atau pemesan yang menurut beberapa informan sebagian besar dari turis asing

\section{Analisis}

Secara teoritis terdapat 2 kategori perubahan sosial, yaitu perubahan yang disengaja atau Intended change dan perubahan yang tidak disengaja atau unintended change Perubahan yang disengaja atau dikehendakj merupakan perubahan yang diperkirakan atau yang telah direncanakan terlebih dahulu oleh pihak-pihak yang hendak mengadakan perubahan di dalam masyarakat Sedangkan perubahan sosial yang tidak disengaja atau tidak dikehendaki, merupakan perubahan yang tidak direncanakan sebelumnya dan berlangsung di luar jangkauan masyarakat, sehingga dapat menimbulkan akibat-akibat sosial yang tidak disangka sama sekali oleh masyarakat (Selo, 1991: 304 -305).

Mengamati perubahan-perubahan sosial di Desa Krikilan sejak didatangi oleh para peneliti asing, khususnya von Koenigswald, dapat dikatakan bahwa perubahan yang terjadi pada awainya lebih bersifat unintended change atau perubahan yeng tidak disengaja Perubahan yang tidak disengaja ini merupakan pangkal terjadinya perubahan-perubahan sosial lain yang menyertainya termasuk didalamnya perubahan yang disengaja (intended change) Karena pada awalnya tidak disengaja maka seringkali perubahan-perubahan tersebut tidak dapat diduga oleh pelaku perubahan itu sendiri Banyak perubahan sosial lain yang membingungkan masyarakat, bahkan mungkin ditentang oleh masyarakat lain di luar Desa Krikilan Perubahan pada hakekatnya tidak harus diartikan ke suatu orientasi kemajuan (progress) namun dapat pula berarti kemunduran dari bidang-bidang kehidupan lain (Soekanto. 1991, 335)

\subsection{Perubahan Tidak Disengaja}

Perubahan yang tidak disengaja di Desa Krikilan termujud dalam bentuk perubahan konsep berkenaan dengan persepsi masyarakat terhadap Benda Cagar Budaya. Sebelum kedatangan von Koenigswald pada tahun 1034, persepsi masyarakat Desa Krikilan terhadap benda peninggalan Situs Sangiran (fosil) adalah bersifat magis yang diyakini mampu menyembuhkan beberapa penyakit Namun sejak kehadiran para peneliti asing yang berusaha mengumpulkan koleksi fosil guna kepen. tingan perkembangan ilmu pengetahuan khususnya paleoantropologi. per. 
sepsi nilai magis yang lama dipegang oleh masyarakat Desa Kitkilan berubah menjadi nilai ekonomis.

Jika berpegang pada konsep kebudayaan yang menyatakan, segala tindakan yang diperoleh dengan cara belajar (Koentjaraningrat, 1890 170. 185), maka dapat dikatakan bahwa penyebab perubahan masyarakat Desa Krikilan adalah pengaruh dari "kebudayaan" para peneliti asing. Apalagi dalam perburuan fosil itu von Koenigswald menerapkan sistem perangsang berupa upah bagi penduduk yang berhasil menemukan fosil Sistem upah semacam ini cukup memancing perhatian masyarakat Desa Krikilan yang rata-rata memiliki taraf hidup yang rendah. Secara tidak langsung usaha pencarian fosil diperkenalkan oleh von Koenigswald pada tahun 1934 tanpa disadari telah mengubah persepsi sekaligus pola perilaki masyarakat Desa Krikilan terhadap nilai suatu fosil

Perubahan semacam ini oleh Rogers dan Shoemaker disebut sebaga! perubahan kontak, yaitu perubahan yang berasal dari luar sistem sosiai Sedangkan lawan dari perubahan kontak adalah perubahan imenen yaitu jika sumber ide baru berasal dari dalam sistem sosial itu sendiri (Rogers dan Shoemaker. 1971: 8-10). Menurut Selo Sumarjan proses perubatian yang tidak di sengaja pada umumnya akan berkembang di luar penga. wasan suatu bagian masyarakat dan akan menimbulkan akibat sosial yang sama sekali tidak disangka oloh masyarakat itu séndiri (Selo, op cit, 305) Di samping itu, tidak ada perubahan sosial yang dapat berdiri sendiri Suatu perubahan biesanya akan selalu diikuti oleh perubahan-perubahar dalam masyarakat yang berhubungan dengan perubahan itu sendir: (Robert, 1993: 21).

Demikian pula yeng terjadi di Desa Krikilan, sepenınggal von Koenigswald pada tahun 1940 dari kawasan situs purbakala Sangiran, penduduk Desa Krikilan tetap melakukan aktivitas yang sama yakni berburu fosil sebanyak-banyaknya untuk di jual kepada orang yang membutuhkan. Perubahan perilaku tersebut berlangsung terus dan telah mencapai perkembangannya hingga sekarang seiring dengan perubahan.

Perubahan lain yang menyertai dalan konteks ini, antara lain nampak jelas oleh perubahan kelembagaan yang terwujud dalam bentuk pendirian Museum Sangiran sebagai penyimpan fosil. Akibat pendirian museum itu, berakibat munculnya berbagai industri rumah berupg industri kerajinan batuan di Desa Krikilan yang sengaja memproduksi berbagai cindera mata untuk para wisatawan pengunjung museum Dampak kehadiran industri kerajinan batuan (fosil) pada tahun 1980-an mengakibatkan perubahan perilaku baik berkaitan dengan aspek perubahan di bidang mata pencarian dari buruh tani ke buruh industri, maupun perubahan perilaku masyarakat terhadap bende warisan budava Artinya di satu pihak keberadaan industri

Berkala Arkeologi Th. XM - (2) - 
rumah itu dapat menciptakan lapangan kerja yang akhirnya mampu meningkatkan pendapatan mereka. Namun pada sisi lain, dalam prakteknya beberapa sentra industri ini justru dimanfaatkan oleh sekolompok orang tertentu sebagai wadah atau "kedok" untuk mengekploitasi fosil dalam bentuk pemalsuan dan perdagangan fosil Sangiran (Sulistyanto 1996).

\subsection{Faktor Pendorong Perubahan.}

Namun demikian suatu perubahan persepsi seperti yang tercermin dalam perilaku mesyarakat Desa Krikilan sekarang ini, tidak mungkin dapat berkembang tanpa adanya faktor pendorong. Di antara berbagai faktor pendorong yang mempengaruhi perubahan pola perilaku tersebut adalah

\subsubsection{Cltra Kurang Ealk Pemerintah}

Citra kurang baik pemerintah di mata masyarakat Desa Krikilan, menyebabkan warga Desa ini merasakan kekecewaan yang berakibat semakin menipis kepeduliannya terhadap nilai-nilai penting benda warisan budaya. Buruknya citra pemerintah di mata masyarakat, salah satunya tercermin pada pemberian ganti rugi pemerintah terhadap para penemu fosil Menurut penuturan beberapa penduduk, pemerintah dalam proses permberian ganti rugi terhadap hasil temuan penduduk relatif kecil dan memakan waktu yang sangat lama sampai bertahun-tahun. Perasaan ke-kecewaan di atas tercermin dalam ungkapan kalimat, "Museum (Sangiran) sampun dangu taksih gadah utang katah kallan penduduk". Kalimat klise itu dipergunakan oleh warga Desa Krikilan untuk mengungkapkan sikap yang cenderung lebih memilih menyerahkan temuan fosil yang utuh kepihak pedagang benda kuna atau tengkulak daripada ke pemerintah.

\subsubsection{Tladanya Lapangan Pekerjaan}

Tiadanya lapangan pekerjaan menyebabkan perburuan dan perdagangan fosil menjadi semakin meningkat. Apalagi munculnya industri rumah berupa kerajinan batuan di Desa Krikilan yang kurang terkoodinir, secara tidak langsung menjadi wahana bagi penyaluran pengangguran mereka yang pada gifirannya ikut mendorong perubahan perilaku masyarakat dari buruh tani ke buruh industri. Dan di dalam prakteknya beberapa sentra industri ini justru dimanfaatkan oleh sekolompok orang tertentu sebagai wadah atau "kedok" untuk mengekploitasi dalam bentuk pemalsuan dan perdagangan $B C B$ Sangiran 


\subsubsection{Rendahnya Taraf Hidup.}

Kondisi perekonomian masyarakat yang rendah, merupakan permasalahan yang cukup mendasar yang mendorong mereka mudah terpengaruh pada perubahan. Apalagi perubahan berkenaan dengan perilaku terhadap fosil yang dirasakan dapat membantu meningkatkan taraf hidupnya

\section{Kesimpulan}

Perubahan sosial yang terjadi di Desa Krikilan dapat dibagi dalam dua kategor, yaitu perubahan yang disengaja dan perubahan yang tidak disengaja. Perubahan yang disengaja adalah perubahan yang telah diketahui dan direncanakan sebelumnya oleh para pelopor perubahan. Perubahan yang disengaja ini nampak jelas pada perubahan kelembagaan yaitu berupa pendirian Museum Sangiran dan merebaknya industri kerajinan batuan. Perubahan-perubahan tersebut berdampak pada perubahan-perubahan lain yang menyertainya antara lain pergeseran dalam mata pencarian hidup dari pertanian ke industri.

Adapun perubahan yang tidak disengaja, berupa perubahan ideologis berkenaan dengan nilai dasar keyakinan mereka tentang konsepsi suatu benda warisan budaya (fosil) dari religius-magis ke ekonomis. Perubahan tersebut menjadi pangkal terjadinya perubahan-perubahan sosial lainnya Karena tidak disengaja maka perubahan tersebut tidak dapat diduga oleh pelaku perubahan itu sendiri.

Dengan demikian tanpa disadari, perubahan ini sebenarnya "diprakarsai" oleh von Koenigswald yang dibantu dan dilanjutkan oleh Kepala Desa Seternpat Toto Marsono. Dalam konteks ini, dua tokoh tersebut dapat dipandang telah memainkan peranan sebagai agents of change atau pelopor perubahan yang sebetulnya tanpa direncanakan dan diduga akibatnya.

Sebagai dampak dari perubahan konsep dasar tersebut, maka perilaku mereka pun juga ikut mengatami perubahan, sebagai pemburu fosil yang tidak pernah dilakukan pada masa-masa sebelumnya Perubahan sosial pada hakekatnya tidak dapat dipandang sebelah mata, sebab akan diikuti oleh perubahan-perubahan di bidang lain Jika dahulu warga Desa Krikilan murni sebagai petani atau buruh tani, dengan munculnya sentrasentra Industri kerajinan, mereka khususnya para wanita sekarang lebih memilih pekerjaan sebagai buruh industri.

Seperti konsep perubahan sosial pada umumnya, bahwa perubahan sosial akan mengikuti proses integrasi disusul dengan disintegrasi dan kemudian reintegrasi. Maksudnya di sini ialah bahwa sebelum kedatangan para peneliti asing, warga Desa Krikilan memiliki norma-norma sosial yang 
hidup dan lama dinayati oleh masyarakat. Di sini sifatnya integrasi Karena pengaruh budaya peneliti asing, maka norma yang semula menunjukkan gejala integrasi itu pudar dan mengalami proses disintegrasi Artinya masyarakat atau sebagian masyarakat yang terpengaruh menganggapnya tidak sesuai lagi dengan tata kehidupan yang baru

\section{Kepustakaan}

Anonim, 1992, Kabupaten Daerah Tingkat II Sragen Dalam Angka, Kantor Statistik BAPPEDA, Kabupaten Sragen.

Azwar, Saifuddin, 1988, Sikap Manusia Teori dan Pengukurannya. Yogyakarta, Liberty Chapin, Stuart, 1958. Cultural Change. New York: Century Company

Koentjaraningrat (editor). 1992, "Ciri-ciri Dari Kehidupan Masyarakat Pedesaan di Indonesia" dalam Sajogjo \& Pudjiwati Sajogjo. Sosiologi Pedesaan I, Yogyakarta, Gadjah Mada University Press.

Lauer. H, Robert, 1993,Perspektif Tentang Perubahan Sosial, Terjemahan Ali Mandan, Jakarta: Rineka Cipta.

Mantri Statistik. Kecamatan Kalijambe Dalam Angka Tahun 1993

Moore Frazier,H, 1987. Hubungan Masyarakat Prinsip dan Masalah. Bandung, Remaja Rosdakarya

Nimpoeno, S J. John, 1981 "Fungsi Warisan Sebagai Pembentuk Sikap Terhadap Pembangunan". Dalam Analisa Kebudayaan Jakarta: Departemen Pendidikan dan Kebudayaan. 
Parsudi Suparlan, 1986. Perubahan Sosial dalam Manusia Indonesia Individu Keluarga dan Masyarakat (ed) A.W Widjaya Jakarta Akademika Pressindo.

Rogers M Everett \& Shoemaker F Floyd, 1971. Communication of Innovation. New York: The Free Press

Slamet OS 1994, Koordinasi Pengembangan Cagar Budaya Sangiran dalam kaitannya dengan Pemanfaatan Panwisata Makalah pada Evaluasi Hasil Studi Teknis Pengembangan Cagar Budaya Sangiran. Surakarta, 4-6 1994

Soemardjan, Selo, 1991. Perubahan Sosial di Yogyakarta Terjemahan H.J Koesoemanto. Yogyakarta Gadjah Mada University

Soekanto, Soerjono, 1986, Sosiologi Suatu Pengantar. Jakarta. Rajawali Pers.

Sorokin, 1941. Social and Cultural Dynamics New York American Book Co.

Soelistyanto, B. (1995). Perilaku Masyarakat Terhadap Benda Cagar Budaya Sangiran: Studi Kasus Di Desa Krikilan. Berkala Arkeologi, 15(1), 46-64. https://doi.org/10.30883/jba.v15i1.654

Soelistyanto, Bambang, 1995, Sikap dan Perilaku Masyarakat Sangiran Terhadap Benda Cagar Budaya dalam Harry Widianto dkk, Laporan Penelitian Sangiran Penelitian Tentang Manusia Purba, Budaya dan Lingkungan Berita Penelitian Arkeologi No 46 Jakarta Puslit Arkenas 